\title{
Thermal effects of the North Atlantic Oscillation on the cold period of the year in Lithuania
}

\author{
Arunas Bukantis $^{1, *}$, Galina Bartkeviciene ${ }^{2}$ \\ ${ }^{1}$ Department of Hydrology and Climatology, Vilnius University, M. K Ciurlionio 21, 03101 Vilnius-9, Lithuania \\ ${ }^{2}$ Department of Terrestrial Ecosystems, Institute of Ecology, Vilnius University, Akademijos 2, 08412 Vilnius-21, Lithuania
}

\begin{abstract}
The impact of the North Atlantic Oscillation (NAO) on long-term air temperature fluctuations in Lithuania was studied for the period 1865 to 2000. Mean monthly values of 2 NAO indices (NAO-1, NAO-2) and air temperatures at 9 Lithuanian meteorological stations were used as references. Synoptic situations, as well as the mean sea level pressure (SLP) and $500 \mathrm{hPa}$ geopotential height field of a total of 265 months, were analysed. NAO conditions were classified as positive, negative or neutral. Air temperature fluctuations in Lithuania during the cold period of the year (November to March) are positively correlated with fluctuations of the NAO indices. During periods of extreme NAO indices $(|I|> \pm 1.5 \sigma)$, a negative NAO phase is usually correlated (75 to $88 \%$ of the cases) to negative temperature anomalies, whereas a positive NAO phase is correlated to positive temperature anomalies. In the other cases, reverse impact of positive and negative NAO patterns, the relation between NAO phases and regional temperature anomalies is opposite or not detectable. Also, this study includes the analysis of atypical periods of NAO-like circulation: when positive NAO phase was related to negative temperature anomalies and negative NAO phase to positive temperature anomalies in Lithuania.
\end{abstract}

KEY WORDS: NAO · Indices · Temperature anomaly $\cdot$ Lithuania $\cdot$ Synoptic climatology Resale or republication not permitted without written consent of the publisher

\section{INTRODUCTION}

The North Atlantic Oscillation (NAO), one of the major atmospheric processes of the Northern Hemisphere, is the most distinctive low-frequency fluctuation feature of North Atlantic atmospheric circulation. It consists in large-scale irregular fluctuations of atmospheric pressure at sea level (SLP) in the baric formations of the Icelandic and Azores regions. The NAO reflects the middle latitudinal dynamics of air mass flow from west to east between these North Atlantic centres of atmospheric action (Trigo et al. 2002).

NAO impacts on winter climate in the Northern Hemisphere, particularly in the Atlantic-European sector, have been anlysed by Hurrell (1995), Rogers (1997), Quan et al. (2000), and Hurrell et al. (2002). The temperatures of the ocean surface and of the atmospheric boundary layer are closely associated with NAO indices in most regions of the Northern Hemisphere- the North Atlantic water areas, eastern North America, the Arctic region, Eurasia and the Mediterranean region (Hurrell \& van Loon 1997, Hurrell 2000).

During the positive NAO phase, when circulation over the North Atlantic is intensified, warming takes place and the amount of precipitation increases in northern Europe. Cooling and a decrease in precipitation occur in southern and central Europe. The reverse occurs when circulation over the North Atlantic weakens (Fowler \& Kilsby 2002, Hurrell et al. 2002). Such changes in temperature and precipitation due to the dynamics of the NAO index are apparent not only along the North Atlantic coasts, but also on large continental sectors on both sides of the ocean. This is evidenced by the relation of NAO index variability to fluctuations in river runoff in North America and Europa (see Smirnov et al. 1998).

The contribution of change in NAO to the current global and hemispheric mean winter temperature 
trend is of particular interest (Grey et al. 2000). According to Hurrell (1996), both NAO and the El Niño/Southern Oscillation (ENSO) have a linear relation with this climatic trend, but the NAO impact on terrestrial temperatures in the Northern Hemisphere is greater than that of ENSO.

NAO phases may influence human economic activities, agricultural crops (duration of the vegetation period, thermal moisture indices), sea navigation, fisheries, the ecological state of regions, and the functioning of terrestrial and aquatic ecosystems . (Marshall et al. 2001). Development, reproduction and demography of many animals, migration timing and routes of birds, including their hatching places, are also linked with NAO fluctuations (Ahola \& Sippola 2003, Hüppop 2003, Seather 2003).

The entire European region is in the impact zone of western flows from the Atlantic Ocean, where the precipitation, temperature and the runoff regime, as well as sea water level variations and ice formation conditions, are for the most part preconditioned by the NAO. Therefore, we investigated climatic effects in Lithuania that result from the NAO impact, focusing on thermal effects of the NAO during the cold period of the year.

\section{METHODS}

Mean air temperatures of 9 meteorological stations (MS; see Fig. 3) were employed in this study. Air temperature anomalies, $\Delta t\left({ }^{\circ} \mathrm{C}\right)$, were calculated on the basis of the climatic mean for 1961 to 1990. The datasets differed in duration: the longest is of Vilnius MS (1865 to 2000), whereas the other MSs had data from 1948 to 2000. The data are homogeneous (Bukantis et al. 1998).

Previous research established that the impact of atmospheric circulation on meteorological variables in the Baltic region is particularly strong from November to March. The advection process in the eastern Baltic Sea region is dominant, forming from 42 to $54 \%$ of the total dispersion in the variation of meteorological variables (Bukantis 2002).

The NAO-1 Index for 1865 to 2000, based on the difference of normalised SLP between Ponta Delgada (Azores) and Stykkisholmur/Reykjavik (Iceland), was obtained from the NCAR Climate Analysis Centre (Hurrell 1995).

The NAO-2 Index for 1865 to 2000, based on the difference of normalised SLP between Gibraltar and Stykkisholmur/Reykjavik, was obtained from the Climate Research Unit, University of East Anglia (Jones et al. 1997). The NAO indices ( $I$ ) were classified as low or high when they satisfied the inequality $|I|> \pm 1.5 \sigma$, where $\sigma$ is the standard deviation of the dataset for $I$.
The study also used SLP field and $500 \mathrm{hPa}$ height field data from the NOAA-CIRES Climate Diagnostics Centre (CDC) and NCEP/NCAR Reanalysis Electronic Database (Kalnay et al. 1996). All data are monthly mean values for the cold period of the year (November to March) and include the period from1948 to 2000 in the Atlantic-European sector at 20 to $90^{\circ} \mathrm{N}$ latitude and $70^{\circ} \mathrm{W}$ to $70^{\circ} \mathrm{E}$ longitude. The data resolution is a regular grid of $2.5 \times 2.5^{\circ}$ latitude and longitude.

The atmospheric circulation mechanisms of damping of the NAO-like circulation (during the positive NAO phase, and negative air temperature anomalies) or isolation of the NAO impact (negative NAO phase and positive air temperature anomalies) were also analysed for Lithuania. Synoptic situations were classified according to their thermal effects, on the basis of (1) position and intensity of the atmospheric centres of action of the Icelandic Low and the Azores High, as well as the location of troughs and ridges in the SLP field; (2) geographical location, sign and amplitude of SLP anomalies; (3) location of upper troughs and ridges at $500 \mathrm{hPa}$ and dominant flow over Lithuania; (4) position of the centres of geopotential height anomalies, and sign and amplitude of $500 \mathrm{hPa}$ height deviations and the change in their gradients over Lithuania.

The Wilcoxon and Mann-Whitney-Wilcoxon RankSum tests for non-parametric statistics were employed to determine the significance of the linear correlation coefficients between mean air temperature at Vilnius MS and the NAO-1 and NAO-2 indices.

\section{NAO IMPACT ON LONG-TERM AIR TEMPERATURE FLUCTUATIONS}

Air temperature in Lithuania is strongly influenced by the Atlantic Ocean and the distance from the Baltic Sea (Bukantis 1994).

Linear correlation coefficients between NAO indices and monthly mean air temperature at Vilnius (Table 1) show that the principal NAO impact on temperature occurs from September to March, and that of the NAO-1 Index extends to July and August as well. This is predetermined by high meridional gradients in SLP and geopotential height during the cold period and late summer (Stankunavicius 2001). The strongest correlation of NAO indices with temperature occurs in January to March, when anomalies of SLP and geopotential height are greatest, due to the strong winter correlation of temperature with NAO-2. In spring and summer, when low-gradient baric fields and a weak zonal flow are dominant, the impact of solar irradiation is stronger than that of the atmospheric circulation (Bukantis 2002). A similar dependence of temperature fluctuation on the NAO has been reported from other Baltic countries: in 
Table 1. Correlation coefficients between NAO indices and mean air temperature at Vilnius from 1865 to $2000\left(r_{99} \geq 0.25\right.$; $\left.r_{95 \%} \geq 0.20\right)$

\begin{tabular}{|c|c|c|c|c|c|c|c|c|c|c|c|c|}
\hline & Jan & Feb & Mar & Apr & May & Jun & Jul & Aug & Sep & Oct & Nov & Dec \\
\hline NAO-1 & 0.47 & 0.57 & 0.61 & 0.18 & 0.19 & 0.17 & 0.20 & 0.33 & 0.47 & 0.38 & 0.34 & 0.32 \\
\hline NAO-2 & 0.56 & 0.61 & 0.51 & 0.15 & 0.06 & 0.01 & 0.05 & 0.05 & 0.29 & 0.35 & 0.31 & 0.40 \\
\hline Mean & 0.51 & 0.59 & 0.56 & 0.16 & 0.12 & 0.09 & 0.12 & 0.19 & 0.38 & 0.36 & 0.32 & 0.36 \\
\hline
\end{tabular}

Poland, the mean minimum and maximum temperatures are correlated with the NAO index (except during summer); the strongest correlation is between NAO and mean maximum temperature in winter (Wibig \& Głowicki 2002).

The positive linear correlation between mean winter (January to March) temperature at Vilnius MS for 1865 to 2000 and NAO-1 was not significant at the $95 \%$ confidence level according to Student's $t$-test. Negative temperature deviations from the long-term winter mean were dominant in the second half of the 19 th century and the middle of the 20th century, whereas positive deviations prevailed in the early 20th century and since 1980. These temperature fluctuations coincide with those of NAO-1. The lowest temperature occurred in $1940\left(-11.0^{\circ} \mathrm{C}\right)$ and $1942\left(-11.5^{\circ} \mathrm{C}\right)$, when the indices were negative. The year 1990 $\left(+2.0^{\circ} \mathrm{C}\right)$, which had the highest temperature, coincides with a maximal value of NAO-1 and NAO-2 (Fig. 1).

\section{AIR TEMPERATURE ANOMALIES AND EXTREME NAO INDICES}

Negative NAO phases usually correspond to negative temperature anomalies, and positive NAO anomalies to positive temperature anomalies (Fig. 2). With extremely high values of NAO indices $(\Delta I>1.5 \sigma), \Delta t$ is positive in 84 to $88 \%$ of the months across Lithuania; with an extremely low NAO index $(\Delta I<-1.5 \sigma), \Delta t$ is negative in 77 to $86 \%$ of the months. The strongest link between air temperature in Lithuania and extreme NAO-1 and NAO-2 indices occurs in December to February. The differences between monthly air temperature anomalies during opposite phases of both NAO indices are statistically significant (Mann-Whitney-Wilcoxon test, 99\% level). Consequently, both indices are adequate for the prediction of temperature anomalies that result from air circulation conditions in Lithuania in December to March.
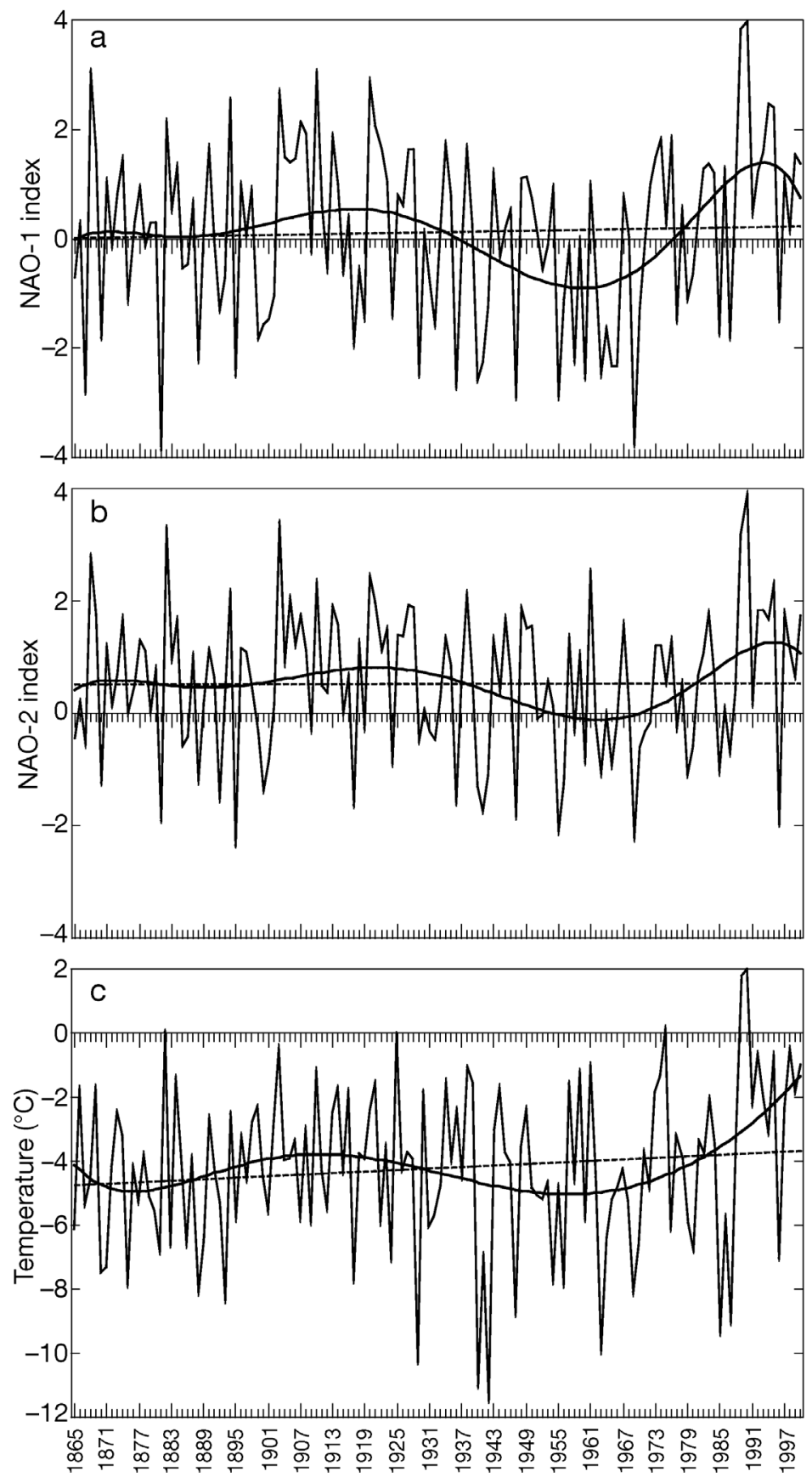

Fig. 1. Long-term winter (January to March) deviations of the (a) NAO1 Index, (b) NAO-2 Index and (c) air temperature $\left({ }^{\circ} \mathrm{C}\right)$ of Vilnius. Solid bold line: polynomial trend; dashed line: linear trend 
For example, February 1989 was characterised by an anomalously intensive zonal air mass transport over Europe, $\Delta t$ values were between +6 and $+7^{\circ} \mathrm{C}$ in Lithuania, the gradient of temperature anomalies was directed from northeast to southwest (Fig. 3a), and the values of NAO-1 and NAO-2 were 4.1 and 3.6, respectively. March 1962 witnessed the opposite: the westerly flow was blocked in the entire Atlantic-European sector, and a cold trough developed over north and central Europe. NAO-1 and NAO-2 values were extremely low ( -5.3 and -3.8 , respectively), resulting in strong negative temperature anomalies in Lithuania $\left(-4\right.$ to $\left.-6^{\circ} \mathrm{C}\right)$, and the direction of the temperature gradient was nearly climatic from southwest to north (Fig. 3c).
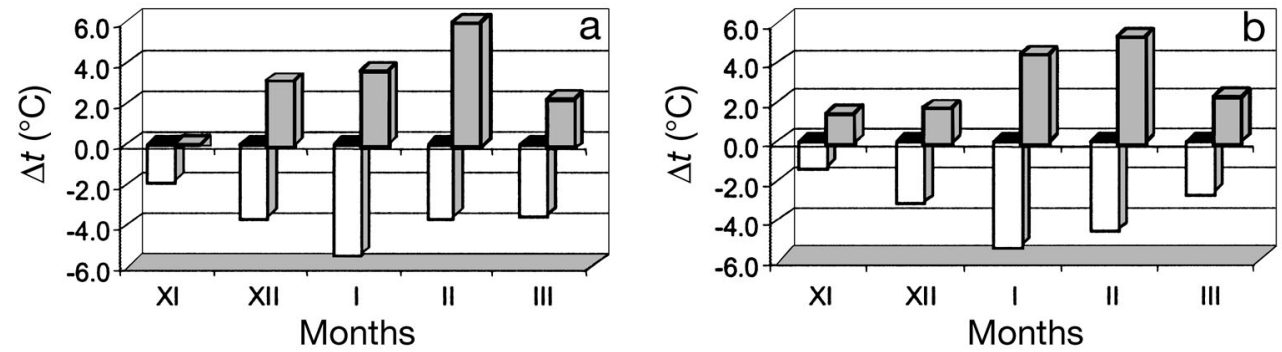

$\square \mathrm{NAO+}$

$\square$ NAO-

Fig. 2. Air temperature anomalies $\left(\Delta t,{ }^{\circ} \mathrm{C}\right)$ from November to March in Lithuania during the period of low (NAO-) and high (NAO+) indices: (a) NAO-1; (b) NAO-2
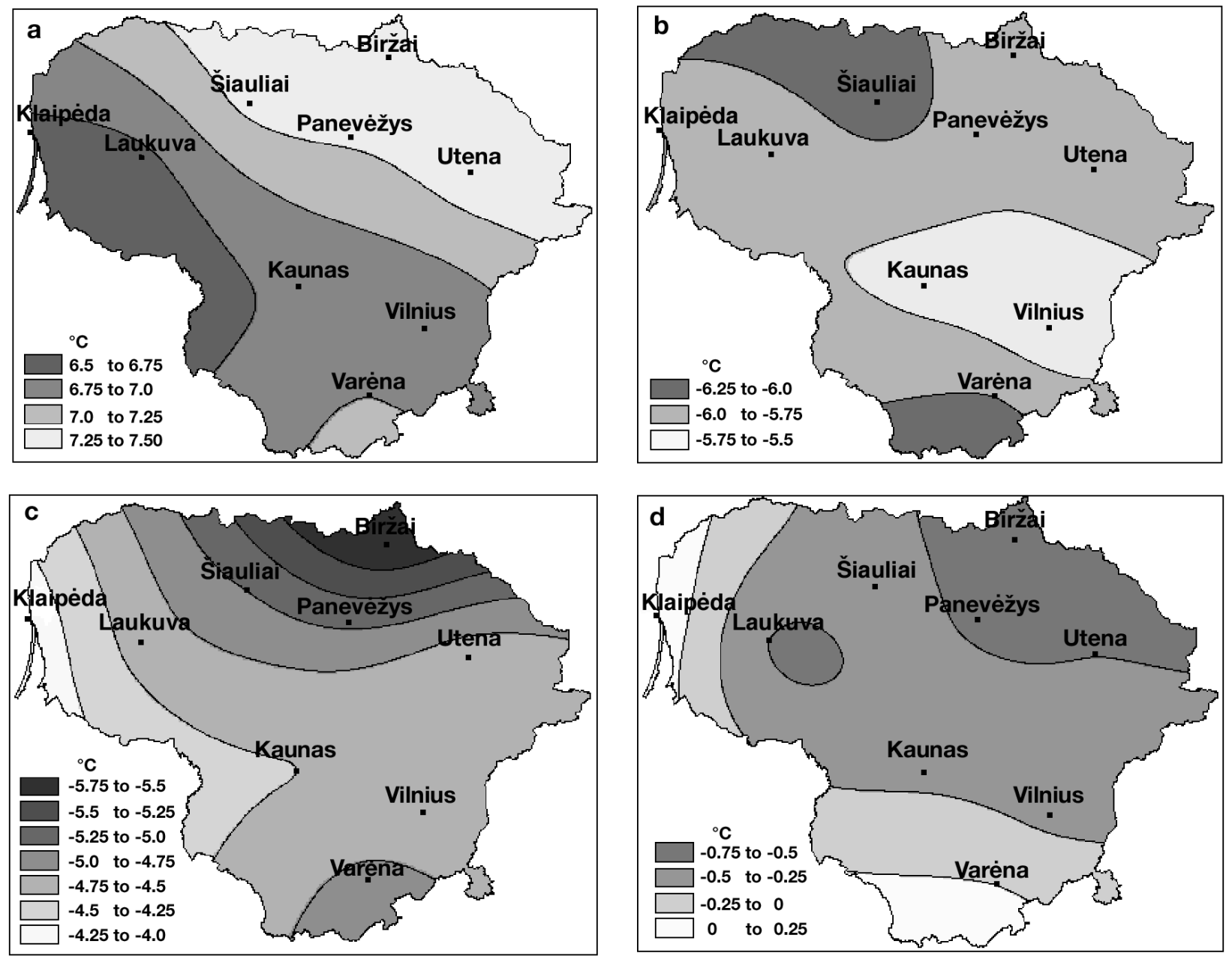

Fig. 3. Air temperature anomalies $\left(\Delta t,{ }^{\circ} \mathrm{C}\right)$ in Lithuania: (a) in February 1989, (b) November 1993, (c) March 1962, (d) January 1977 
Nevertheless, NAO indices do not always represent the impact of atmospheric circulation on the surface temperature field in Lithuania. An unusual opposite thermal effect of the NAO impact was observed in November 1993: though the zonal circulation prevailed in the NAO centres of action in the North Atlantic, the values of the NAO-1 and NAO-2 were positive (3.7 and 0.8, respectively), and a blocking anticyclone developed. Due to cooling that resulted from prevailing low-level cloudiness, negative $\Delta t$ values occurred ( -5.6 to $\left.-6.1^{\circ} \mathrm{C}\right)$ (Fig. $\left.3 \mathrm{~b}\right)$.

Another atypical situation developed in January 1977, when extremely low values of NAO-1 and NAO-2 ( -2.7 and -2.4 , respectively), led to $\Delta t \approx 0$ (Fig. 3d). The extremely negative values of NAO-1 and NAO-2 indices of the above-specified month were determined by large-scale Rossby waves over the Atlantic-European sector: the upper ridges were over the central North Atlantic and east Europe, the upper trough was over west Europe, and the dominating southern and southwestern air flow was over in Lithuania (Stankunavicius \& Bartkeviciene 2003).

In the 1948 to 2000 period, the relation of air temperature to the NAO-1 Index was atypical in $8.3 \%$ of the cases in the November to March interval, and for the NAO-2 Index in 7.5\% of the cases (total: 265 cases). These cases were classified into 2 groups: (A) damping of the NAO impact (positive NAO index and negative $\Delta t$ ), and (B) isolation of the NAO impact (negative NAO index and positive $\Delta t$ ).

\section{REVERSE IMPACT OF THE NAO PATTERNS}

The reverse thermal effect of the positive NAO phase occurred more often than that of the negative NAO phase. Group A included $5.3 \%$ of the cases according to the NAO-1 Index and $4.5 \%$ according to the NAO-2 Index; according to both indices cases of Group B equally accounted for $3 \%$. A detailed analysis was made only of those cases from November to March when both NAO indices were positive or negative, and $\Delta t$ was the opposite, i.e. for those cases when the NAO impact was damped or isolated.

When the NAO impact on the thermal regime in Lithuania is damped, the atmospheric circulation can be of 2 types. Type A1 includes the situations when the location of surface pressure centres and the $500 \mathrm{hPa}$ height anomalies over the North Atlantic centres of action are typical of a positive NAO phase. The zonal flow from the west to the Baltic region is blocked by an intensification of the Siberian anticyclone, which then occupies nearly the entire European region. The upper ridge appears over east Europe (this is atypical of the positive NAO phase), and drives the Atlantic flow
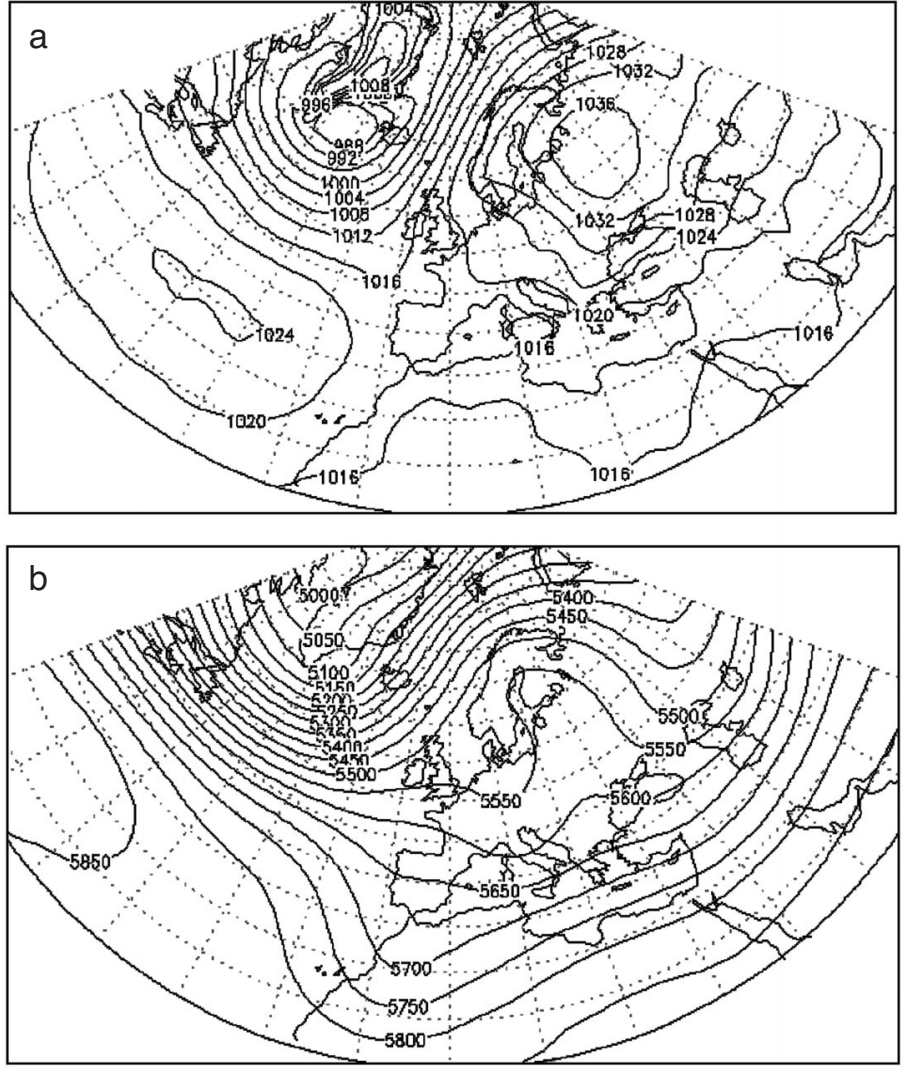

Fig. 4. Circulation patterns during the damping of westerly flow (Type A1): (a) sea level pressure (hPa), (b) $500 \mathrm{hPa}$ geopotential height field (gpm) in the Atlantic-European region in November 1993

towards the northeast. The weather in Lithuania is then subject to Scandinavian and Siberian anticyclones (Fig. 4).

During a period of Type A2, atmospheric circulation in the Atlantic-European region is different from that of Type A1: the ridge extending from the Azores anticyclone to South Scandinavia directs the flow from the Atlantic to the northeast. A field of higher pressure $\left(p_{o}>1013 \mathrm{hPa}\right)$ is located over Lithuania, which is atypical of the positive NAO phase in winter. The upper ridge in the eastern part of the North Atlantic, as well as the upper trough over the Baltic region form favourable conditions for the advection of cold air into Lithuania from the northwest. Therefore, during the period of the positive NAO phase, negative $\Delta t$ develop in Lithuania (Fig. 5).

Isolation of the negative NAO phase impact on Lithuania is characterized by 2 types (B1 and B2) of atmospheric circulation processes of Group B. These did not occur in January and February; they were mostly common in November and March.

Type B1 includes situations when SLP over the North Atlantic is characteristic of the negative NAO phase, 

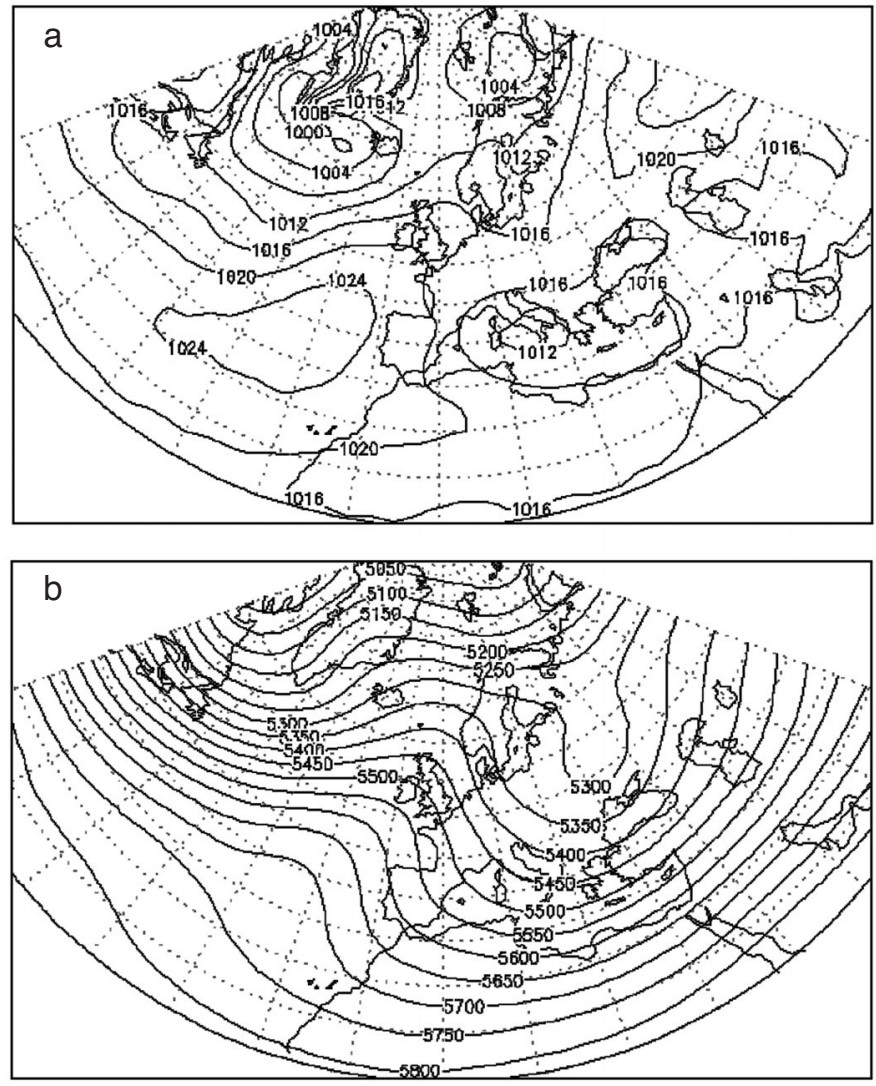

Fig. 5. Circulation patterns during the damping of the westerly flow (Type A2) in January 1954. See Fig. 4 for explanation

but the typical damping processes of the zonal circulation become weaker due to intensification of the Siberian anticyclone. The upper trough develops over the North Atlantic in the $500 \mathrm{hPa}$ height field, and the indistinct upper ridge, which is atypical of the negative NAO phase, extends over Europe. The latter leads to a southwest-north air mass flow to Lithuania, and positive $\Delta t$ result from the influence of Mediterranean and Atlantic cyclones; the SLP is lower or close to the longterm mean, the $500 \mathrm{hPa}$ height anomalies over Lithuania are negative (Fig. 6).

Atmospheric circulation of Type B2 differs from Type B1 in that the Icelandic depression centre in the surface pressure field is situated closer to northwest Europe (over the Norwegian Sea) and the Azores anticyclone centre is shifted northwestward (from 45 to $55^{\circ} \mathrm{N}$ and 30 to $50^{\circ} \mathrm{W}$ ). The Azores anticyclone occupies the region east of Newfoundland, where the Icelandic lows are usually located. The upper trough, instead of the ridge as in Type B1, forms in the $500 \mathrm{hPa}$ height field over Europe. Also, unlike the $500 \mathrm{hPa}$ height field characteristics typical of the negative NAO phase, the axes of both the upper trough and ridge are located more to the west, and the axis of the upper trough runs along west Europe. Lithuania then lies on the eastern periphery of the upper trough, with westeast isohypses. Negative deviations of SLP from the long-term mean are greater than those of Type B1, and $500 \mathrm{hPa}$ height anomalies are negative. The Atlantic cyclones cause positive deviations in air temperature and precipitation (see Fig. 7).

The dependence of the Lithuanian thermal regime on the NAO during the cold season becomes evident when the undivided process takes place in the whole Atlantic-European sector-the zonal and meridional circulation. Nevertheless, besides the atmospheric circulation, it is always essential to evaluate peculiarities of the thermobaric field in the Arctic and east Europe.

\section{CONCLUSIONS}

Air temperatures in Lithuania during the cold period of the year are strongly related to NAO variations A positive NAO phase usually leads to high tempera-
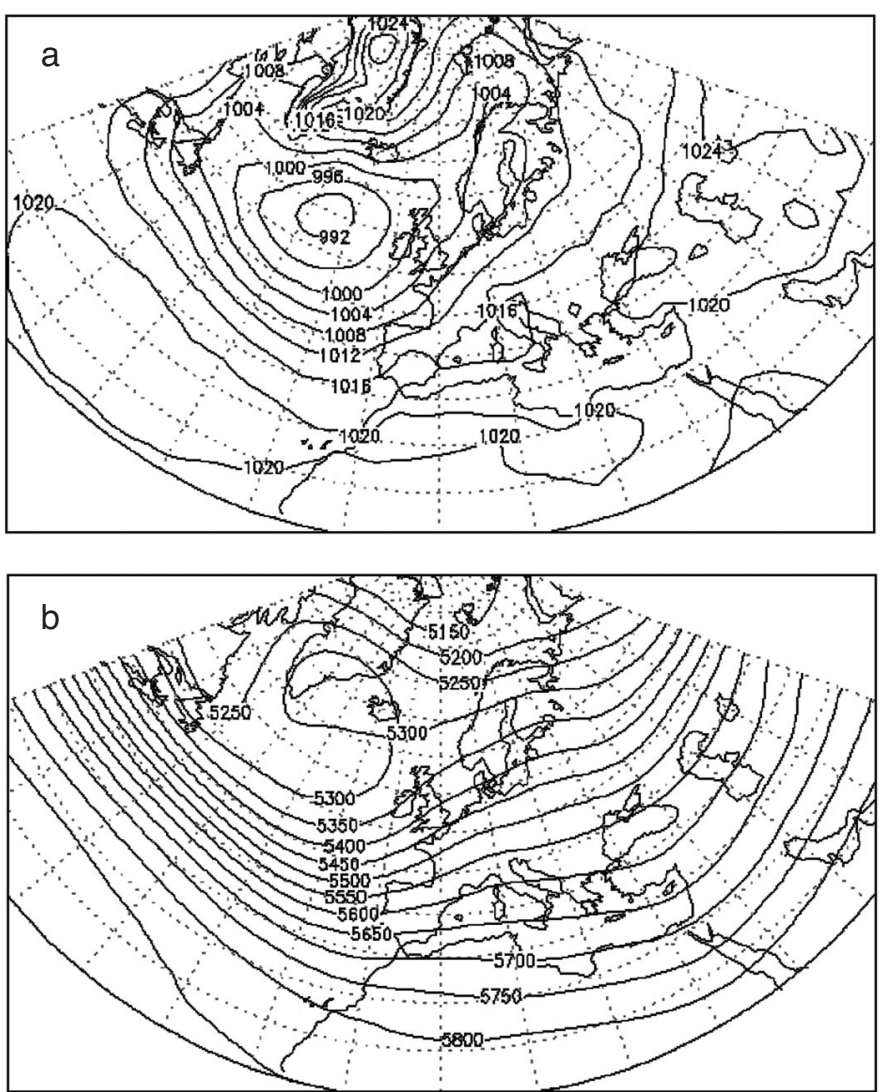

Fig. 6. Circulation patterns when westerly flow is intensified (Type B1) in December 2000. See Fig. 4 for explanation 

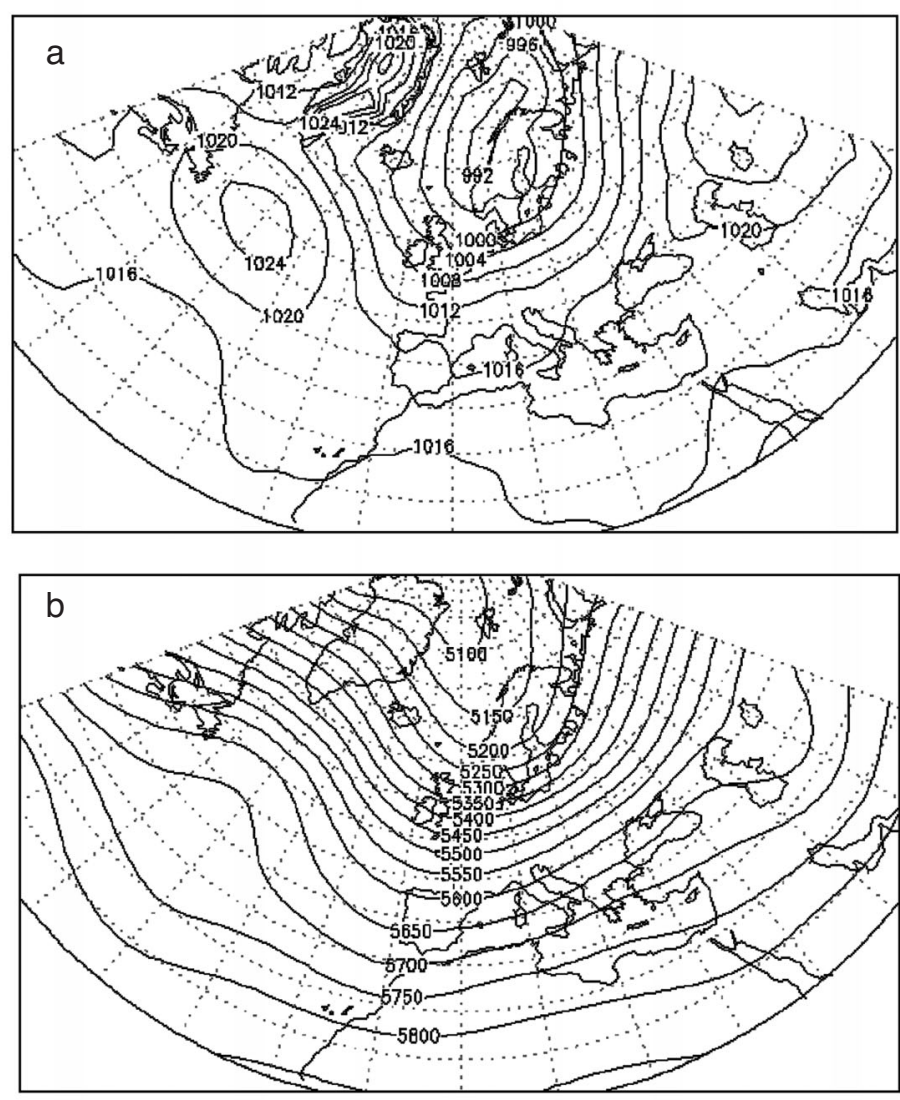

Fig. 7. Circulation patterns when westerly flow is intensified (Type B2) in November 1969. See Fig. 4 for explanation

tures, whereas a negative NAO phase is reflected by low temperatures. During the last 3 decades, winters have become warmer, as a result of more frequently positive NAO indices. The highest NAO indices of the cold period have been recorded in the late 1980s and early 1990s. In the mid-20th century, when negative NAO indices dominated, cold winters increased in frequency in east and central Europe, including in Lithuania. The correlation between the NAO and air temperature fluctuations from April through June are not statistically significant.

NAO indices do not always represent the impact of the atmospheric circulation on surface air temperature in Lithuania during winter. Atypical situations make up about $8 \%$ of the cases, when the NAO index is positive and temperature anomalies are negative (damping of a westerly flow), or when the NAO index is negative and temperature anomalies are positive (isolation of the NAO impact).

During the positive NAO phase, cold anomalies in Lithuania are caused by the Siberian anticyclone, which blocks the zonal flow and leads to the advection of cold Arctic and continental air masses into the Baltic region. In this situation, the Siberian, Scandinavian or North Sea anticyclones determine the weather in Lithuania.

Winter thermal anomalies during the negative NAO phase are caused by southwesterly or westerly flow of air masses to the Baltic region. The Siberian anticyclone is weak and does not block the zonal flow from the Atlantic. The weather in Lithuania is then mostly determined by Atlantic and southern cyclones. Therefore, analysis of weather variability in the Baltic region requires evaluation of the characteristics of the thermobaric field in the Arctic and east Europe, and not only of the North Atlantic atmospheric circulation.

Acknowledgements. The authors thank Dr. G. Stankunavicius of the Department of Hydrology and Climatology of Vilnius University for his constructive criricism and valuable ideas.

\section{LITERATURE CITED}

Ahola M, Sippola K (2003) Timing of breeding and spring arrival of the pied flycatcher in relation to climatic fluctuation: a case study in SW Finland. In: Berthold P, Fiedler W, Moller A (eds) Proc European Science Foundation Workshop 'Bird Migration and Climate Change', University of Constance, Paris, p 10

Bukantis A (1994) Climate of Lithuania. Vilnius University (in Lithuanian)

Bukantis A (2002) Application of factor analysis for quantification of climate-forming processes in the eastern part of the Baltic Sea region. Clim Res 20:135-140

Bukantis A, Kazakevicius S, Korkutis P, Markeviciene I and 5 others (1998) The variability of climatic elements in the Lithuanian territory. Institute of Geography Press, Vilnius (in Lithuanian)

Fowler HJ, Kilsby CG (2002) Precipitation and the North Atlantic Oscillation: a study of climatic variability in northern England. Int J Climatol 22:843-866

Grey SM, Haines K, Troccoli A (2000) A study of temperature changes in the upper North Atlantic: 1950-94. J Clim 13(15):2697-2711

Hüppop O (2003) How are variations in climate and in body condition of spring migrants related? In: Berthold $\mathrm{P}$, Fiedler W, Moller A (eds) Proc European Science Foundation Workshop 'Bird Migration and Climate Change', University of Constance, Paris, p 16

Hurrell JW (1995) Decadal trends in the North Atlantic Oscillation and regional temperatures and precipitation. Science 269:676-679

Hurrell JW (1996) Influence of variations in extratropical wintertime teleconnections on Northern Hemisphere temperature. Geophys Res Lett 23:665-668

Hurrell JW (2000) The North Atlantic Oscillation. Proc 12th Annu Symp Frontiers of Science, Nov 2-4, Irvine, CA. National Academy of Sciences, p 5-27

Hurrell JW, van Loon H (1997) Decadal variations in climate associated with the North Atlantic Oscillation. Clim Change 36:301-326

Hurrell JW, Hoerling MP, Folland CK (2002) Climatic variability over the North Atlantic. In: Pearce R (ed) Meteorology at the Millenium: 150th Anniversary of the Royal Meteorological Society. Academic Press, London, p 143-151 
Jones PD, Jónsson T, Wheeler D (1997) Extension to the North Atlantic Oscillation using early instrumental pressure observations from Gibraltar and South-West Iceland. Int J Climatol 17:1433-1450

Kalnay E, Kanamitsu M, Kistler R, Collins W and 18 others (1996) The NCEP/NCAR Reanalysis 40-year Project. Bull Am Meteorol Soc 77:437-471

Marshall J, Kushnir Y, Battisti D, Chang P and 6 others (2001) North Atlantic climate variability: phenomena, impacts and mechanisms. Int J Climatol 21:1863-1898

Quan B, Corte-Real J, Xu H (2000) Is the North Atlantic Oscillation the most important atmospheric pattern for precipitation in Europe? J Geophys Res 105:11901-11910

Rogers JC (1997) North Atlantic storm track variability and its association to the North Atlantic Oscillation and climate variability of northern Europe. J Clim 10(7):1635-1647

Seather BE (2003) Climate effects on avian population dynamics. In: Berthold P, Fiedler W, Moller A (eds) Proc European Science Foundation Workshop 'Bird Migration

Editorial responsibility: Allen Perry,

Swansea, UK and Climate Change', University of Constance, Paris, p 22 Smirnov NP, Vorobyov VN, Kachanov SY (1998) NorthAtlantic Oscillation and climate. Russian State Hydrometeorological University, St. Petersburg (in Russian)

Stankunavicius G (2001) North Atlantic latitudinal air masses circulation and its impact on weather anomalies. Geography in Lithuania. In: Griniute D (ed) Living in diversity, 29th Int Congr Geographers, Apr 23-25, Vilnius. Institute of Geography and Lithuanian Geographical Society Press, Vilnius, p 216-230 (in Lithuanian)

Stankunavicius G, Bartkeviciene G (2003) The extreme atmospheric circulation conditions in the North Atlantic: the air temperature and precipitation anomalies. Geogr Yearbook 36(1):18-33 (in Lithuanian)

Trigo RM, Osborn TJ, Corte-Real JM (2002) The North Atlantic Oscillation influence on Europe: climate impacts and associated physical mechanisms. Clim Res 20:9-17

Wibig J, Głowicki B (2002) Trends of minimum and maximum temperature in Poland. Clim Res 20:123-133

Submitted: April 22, 2004; Accepted: February 15, 2005

Proofs received from author(s): May 10, 2005 